\title{
Evaluation of Hyperbilirubinemia as a New DiagnosticMarker for Acute Appendicitis and its Role in the Prediction of Appendicular Perforation
}

\author{
Yasser M. Hatata ${ }^{(1)}$, Nader Sh. Zakki ${ }^{(2)}$, Hany Habashy ${ }^{(3)}$ and Fady R.El-said ${ }^{(4)}$. \\ (1) Professor of General and Laparoscopic Surgery, Faculty of MedicineFayoum \\ University. \\ (2) Professor of General and \\ (3) Laparoscopic Surgery, Faculty ofMedicine Fayoum University. \\ (4) Assist. professor of General Surgery, Faculty of Medicine FayoumUniversity. \\ (5) M.B.B.Ch,Department of Surgery, Faculty of Medicine Fayoum University.
}

Corresponding author: prof .Yasser Magdy Hatata

E-mail address: ymh11 @fayoum.edu.eg

Fax: +2 0846302350

Tel:01000351035

\begin{abstract}
Recent studies have shown hyperbilirubinaemia to be a useful predictor of appendicular perforation. Anelevated Serum Total Bilirubin (STB) that is not explained by liver disease or biliaryobstruction can be observed in many patients with acute appendicitis. However there is no confirmatory laboratory marker for the pre-operative diagnosis of acute appendicitis and appendicular perforation. Recently, elevation in serum bilirubin was reported, but the importance of the raised total bilirubin has not been stressed in appendicitis.
\end{abstract}

The aim of this study is to assess the relationship between hyperbilirubinemia and acute appendicitis and to evaluate its credibility as a diagnostic marker for acute appendicitis and also, to see whether elevated bilirubin levels have a predictive potential for the diagnosis of appendicular perforation.

KEY WORDS:, acute appendicitis, appendicular perforation, hyperbilirubinemia.

\section{INTRODUCTION}

Acute appendicitis comes under one of the most frequently encountered cause of "Acute abdomen". Experienced clinicians accurately diagnose appendicitis based on a combination of history, physical examination and laboratory studies about $80 \%$ of The time (1).

Several biochemical parameters including white blood cell (WBC) count, C-reactive protein (CRP), interleukin-6 (IL6) and Procalcitonin have been used to further improve the clinical diagnosis of acute appendicitis (AA). The use of 
Ultrasonography as a diagnostic tool for appendicitis has been widely known and studied (2).

Recently, elevation in serum bilirubin was reported, but the importance of the raised total bilirubin has not been stressed in appendicitis(3).

It is well established that when microbes invade the body, leukocytes defend it. This leads to increase in the leukocyte count. Bacterial invasion in the appendix leads to transmigration of bacteria and the release of proinflammatory cytokines such as TNF alpha, IL6 and cytokines. These reach the liver via Superior mesenteric vein (SMV) and may produce inflammation, abscess or dysfunction of liver either directly or indirectly by altering the hepatic blood flow (4).

Delay in diagnosis and surgery for this condition may lead to various complications like perforation, abdominal abscess, urinary retention, small bowel obstruction and peritonitis causing an increase in morbidity and even mortality of the patients. On the other hand, too aggressive surgical approach may lead to an increased rate of negative appendectomies. The incidence of perforated appendicitis in adults has been reported from 13-37\%(5).

The rate of perforation is reported to increase by $5 \%$ per $12 \mathrm{~h}$ period after $36 \mathrm{~h}$ from the onset of symptoms, therefore, expedient diagnosis and treatment are required (6).

\section{PATIENTS AND METHODS}

This is a prospective study conducted at General Surgery department at Fayoum Faculty of Medicine hospitals, from March 2018 to March 2019. 100 Consecutive cases of clinically diagnosed acute appendicitis admitted in surgical unit were recruited for the study.
These patients were subjected to thorough history taking and clinical examination was done for all patients.

Investigations to support the diagnosis total leucocytes count, differential leucocytes count, urine analysis andultrasound.

These cases were also subjected to liver function test and serum alkaline phosphatase. The serum bilirubin (SB) was determined by semi-automatic analyzer of the blood samples

collected. Subsequently these cases were operated and clinical diagnosis was confirmed post operatively by histopathological examination. Their clinical and investigative data were compiled and analyzed.

\section{RESULTS}

Table (1): Illustrates that all cases show acuteappendicitis, with $78 \%$ of them continue as acute appendicitis without complication but $13 \%$ were complicated with perforation and 9\% complicated with gangrenous appendicitis .

Table (2): Illustrates that there is no statistically significant difference with $\mathrm{p}$ - value $>0.05$ between cases with acute appendicitis and other cases which complicated with perforation as regards different bilirubin level (total, direct, and indirect bilirubin). On the other hand there is statistically significant high mean of total, direct, and indirect bilirubin level with p- value $>0.05$ among cases complicated with gangrenous appendicitis; which indicated increase in total, direct, and indirect bilirubin level when appendicitis complicated with gangrene. 
Table (3): Illustrates that there is no statistically significant difference in total, direct, and indirect bilirubin level, with $\mathrm{p}$ value $>0.05$ between different diagnoses.

On the other hand there is statistically significant higher percentage of indirect hyperbilirubinemia among cases with gangrenous complication with $\mathrm{p}$-value $<0.05$. 


\section{DISCUSSION}

No single clinical or laboratory test is able to reliable predict acute appendicitis or appendicular perforation rather a combination of history, clinical examination and laboratory and radiological investigation is used to make the diagnosis and decide

appropriate management.

Serum Bilirubin level elevation will help in the accuracy of clinical diagnosis of acute appendicitis and more importantly help in foreseeing and preventing complications of acute appendicitis.

There have been several reports of hyperbilirubinemia in appendicitis. Estrada et al hypothesized that hyperbilirubinaemia may be associated with appendicular perforation and showed that more patients with a perforation or gangrenous appendix had hyperbilirubinaemia than those with simple acute appendicitis(7). Sand et al showed that Hyperbilirubinaemia had a specificity of $86 \%$ for appendicular perforation or gangrenous, compared with a specificity of only $35 \%$ for CRP(8).

Several mechanisms leading to hyperbilirubinaemia in systemic infections have been described.

Haemolysis causes an increased

Bilirubin load and has been associated with several bacteria including Escherichia coli.

Another mechanism is reduced hepatic uptake and canalicular excretion of bilirubin caused by endotoxaemia(9). Escherichia coli is associated with the endotoxin lipopolysaccharide and is the most common organism cultured from intraperitoneal fluid in appendicitis(10).

Hyperbilirubinaemia presumably occurs in appendicitis as a result of bacteraemia or endotoxaemia, which could occur both in simple appendicitis and perforated or gangrenous appendicitis.

Hyperbilirubinaemia (>1.0 mg/dL) in our study was found in 66 patients $(66 \%)$ of all the 100 patients enrolled inthe study, while 34 patients $(34 \%)$ had normal bilirubin levels $(<1.0 \mathrm{mg} / \mathrm{dL})$. Patel et al. had found hyperbilirubinaemia in $82(82 \%)$ of 100 patients studied with acute appendicitis (11).

The main finding of the study indicates that patients with complicated appendicitis were significantly more likely to have hyperbilirubinemia than those with acute simple appendicitis.

\section{CONCLUSION}

Total serum bilirubin can be a significant addition to the list of routine investigations laboratory tests at the time of admission in cases of suspected appendicitis, so the diagnosis of Acute Appendicitis early with clinically suggestive signs can be made with fair degree of accuracy and unnecessary or delay in appendectomy can be avoided. 


\section{REFERENCES}

(1) Giordano S, Pääkkönen M, Salminen P, Grönroos JM. Elevated serum bilirubin in assessing the likelihood of perforation in acute appendicitis? A diagnostic meta- analysis. Int J Surg 2013; 11:795-800.

(2) Blab E, Kohlhuber U, Tillawi S, Schweitzer M, Stangl G, Ogris. E, et al. Advancements in the diagnosis of acute appendicitis. Eur J Pediatr Surg 2004; 14:404 -9.

(3) Kim TH, Cho BS, Jung JH, Lee MS, Jang JH, Kim CN. Predictive Factors to Distinguish Between Patients with Noncom plicated Appendicitis and Those with Complicatedapppendicitis. Ann Coloproctol 2015; 31: 192-197.

(4) Whiting JF, Green RM, Rosen AB, GollanJL. TNF-alpha decreases hepatocyte bile salt uptake and mediated endotoxin- induced cholestasis. Hepatology. 1995; 22(4 Pt 1): 1273-8.

(5) Hong YR, Chung CW, Kim JW, Kwon CI, Ahn DH, Kwon SW et al. Hyperbilirubinemia is a significant indicator for the severity of acuteappendicitis. J Korean Soc Coloproctol. 2012; 28:247-52

(6) Ditillo MF, Dziura JD, Rabinovici R. Is It Safe to Delay Appendectomy in Adults With Acute Appendicitis? Ann Surg.2006; 244: 656-660.

(7) EstradaJ J, Petrosyan M, Barnhart J et al. Hyperbilirubinemia in appendicitis: A new predictor of perforation. J Gastrointest Surg2007; 11:714-718.

(8) Sand M, Bechara FG, Holland- Letz T, Sand D, Mehnert G, Mann

B. Diagnostic value of hyperbilirubinemia as a predictive factor for appendiceal perforation in acute appendicitis. Am J Surg 2009; 198:193-8

(9) Bolder U, Tonnu HT, Schteingasrt CD, et al. Hepatocyte transport of bile acids and organic anions in endotoxemic rats: impaired uptake and secretion. Gastroenterology 1997:112:214225.

(10) Baron EJ, Baron R, et al. Amicrobial comparison between acute and complicated appendicitis.Clin Infect Dis 1992; 14:227-231.

(11) Patel D, Shah NJ, Patel B, Parikh M, Dalal C. Evaluation of hyperbilirubinema as a new diagnostic marker for acuteappendicitis and its role in the prediction of complicated appendicitis. Int $\mathbf{J}$ Res Med. 2014; 3:28-33. 
Table (1): Illustrates that all cases show acute appendicitis, with $78 \%$ of them continue as acute appendicitis withoutcomplication but $13 \%$ were complicated with perforation and $9 \%$ complicated with gangrenous appendicitis.

\begin{tabular}{|l|l|l|}
\hline Variables & $\begin{array}{l}\text { Number } \\
(\mathrm{n}=100)\end{array}$ & $\%$ \\
\hline Acute appendicitis & 78 & $78 \%$ \\
\hline Perforated appendicitis & 13 & $9 \%$ \\
\hline Gangrenous appendicitis & 9 & $9 \%$ \\
\hline
\end{tabular}

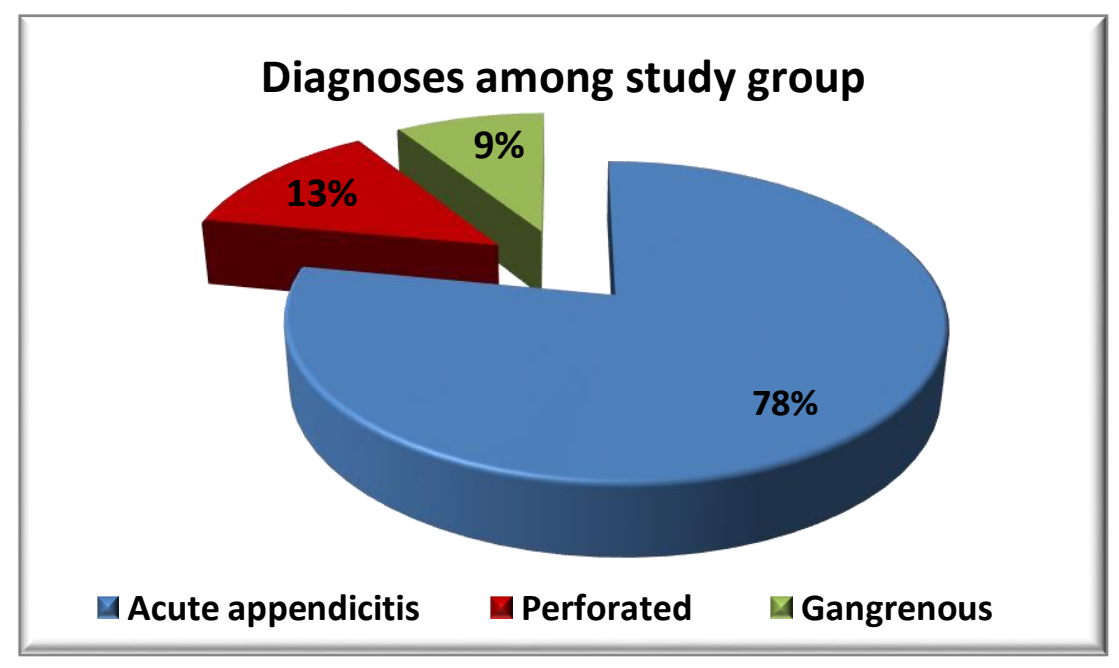

Table (2): Illustrates that there is no statistically significant difference with p-value $>0.05$ betweencases with acute appendicitis and other cases which complicated with perforation as regards different bilirubin level (total, direct, and indirect bilirubin). On the other hand there is statistically significant high mean of total, direct, and indirect bilirubin level with p-value $>0.05$ among cases complicated with gangrenous appendicitis; which indicated increase in total, direct, and indirect bilirubin level when appendicitis complicated with gangrene. 
ISSN: 2536-9474 (Print)

ISSN: 2536-9482 (Online)
Original article / FYMJ

Fayoum University Medical Journal Lotayef et al., 2020,7(1), 16-24

\begin{tabular}{|c|c|c|c|c|c|}
\hline \multirow{3}{*}{ Variables } & \multicolumn{3}{|c|}{ Appendicitis } & \multirow{3}{*}{ p- value } & \multirow{3}{*}{ Sig } \\
\hline & Acute & Perforated & $\begin{array}{l}\text { Gangrenou } \\
\mathrm{S}\end{array}$ & & \\
\hline & $\begin{array}{l}\text { Mean } \\
\pm \text { SD } \\
\end{array}$ & $\begin{array}{r}\text { Mean } \\
\pm \text { SD } \\
\end{array}$ & Mean \pm SD & & \\
\hline $\begin{array}{l}\text { Total } \\
\text { bilirubin }\end{array}$ & $\begin{array}{r}1.33 \\
\pm 0.5 \\
1 \\
\end{array}$ & $\begin{array}{r}1.51 \pm \\
0.55\end{array}$ & $1.84 \pm 0.26$ & $\begin{array}{l}>0.05^{\mathrm{a}, \mathrm{b}} \\
\mathbf{0 . 0 1}\end{array}$ & $\begin{array}{l}\text { NS } \\
\mathbf{S}\end{array}$ \\
\hline $\begin{array}{l}\text { Direct } \\
\text { bilirubin }\end{array}$ & $\begin{array}{r}0.44 \\
\pm 0.1 \\
3\end{array}$ & $\begin{array}{r}0.45 \pm \\
0.09\end{array}$ & $0.57 \pm 0.12$ & $\begin{array}{l}>0.05^{a, b} \\
\mathbf{0 . 0 0 8}\end{array}$ & $\begin{array}{l}\text { NS } \\
\text { HS }\end{array}$ \\
\hline $\begin{array}{l}\text { Indirect } \\
\text { bilirubin }\end{array}$ & $\begin{array}{r}0.89 \\
\pm 0.4 \\
1\end{array}$ & $1.1 \pm 0.52$ & $\begin{array}{c}1.3 \pm \\
0.2\end{array}$ & $\begin{array}{l}>0.05^{a, b} \\
\mathbf{0 . 0 3}^{\mathbf{c}}\end{array}$ & $\begin{array}{l}\text { NS } \\
\mathbf{S}\end{array}$ \\
\hline
\end{tabular}

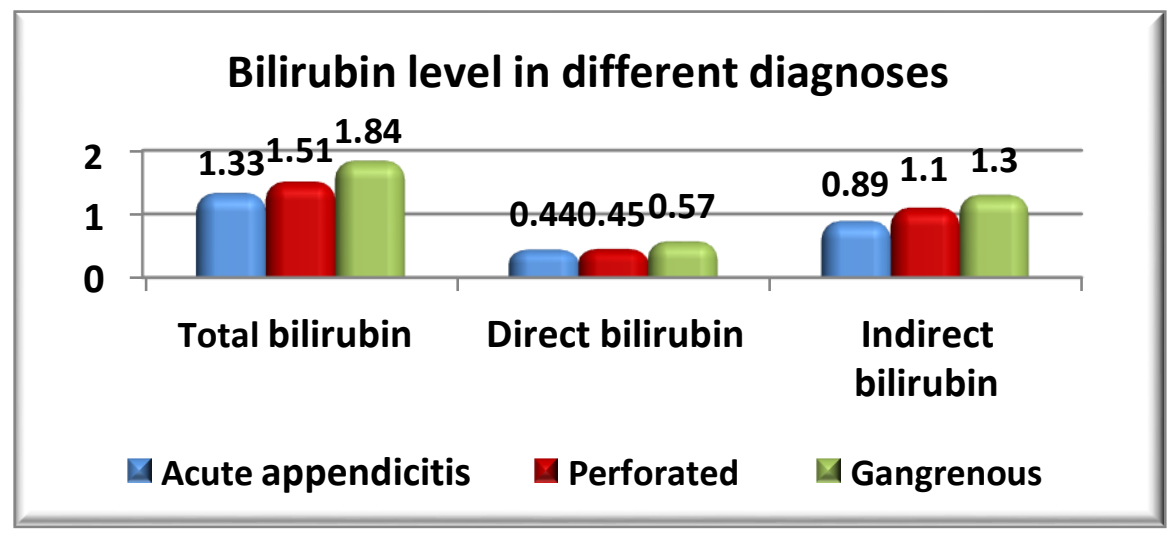


Table (3): Illustrates that there is no statistically significant difference in total, direct, and indirectbilirubin level, with $\mathrm{p}$-value $>0.05$ between different diagnoses.

On the other hand there is statistically significant higher percentage of indirect hyperbilirubinemia among cases with gangrenous complication with $\mathrm{p}$-value $<0.05$.

\begin{tabular}{|c|c|c|c|c|c|}
\hline \multirow{3}{*}{ Variables } & \multicolumn{3}{|c|}{ Appendicitis } & \multirow{3}{*}{$\begin{array}{l}\text { p- } \\
\text { value }\end{array}$} & \multirow{3}{*}{ Sig. } \\
\hline & Acute & $\begin{array}{l}\text { Perforat } \\
\text { ed }\end{array}$ & Gangrenous & & \\
\hline & No. $(\%)$ & No. $(\%)$ & $\begin{array}{l}\text { No. } \\
(\%)\end{array}$ & & \\
\hline \multicolumn{6}{|c|}{ Total bilirubin } \\
\hline$\leq 1 \mathrm{mg} / \mathrm{dl}$ & $\begin{array}{r}30(38.5 \\
\%)\end{array}$ & $\begin{array}{l}4(30.8 \% \\
)\end{array}$ & $0(0 \%)$ & \multirow[t]{2}{*}{0.07} & \multirow[t]{2}{*}{ NS } \\
\hline$>1 \mathrm{mg} / \mathrm{dl}$ & $\begin{array}{r}48(61.5 \\
\%) \\
\end{array}$ & $\begin{array}{l}9(69.2 \% \\
)\end{array}$ & $\begin{array}{r}9(100 \% \\
)\end{array}$ & & \\
\hline \multicolumn{6}{|c|}{ Direct bilirubin } \\
\hline$<0.03 \mathrm{mg} / \mathrm{dl}$ & $\begin{array}{r}19(24.4 \\
\%) \\
\end{array}$ & $\begin{array}{l}2(15.4 \% \\
)\end{array}$ & $0(0 \%)$ & \multirow[t]{2}{*}{0.2} & \multirow[t]{2}{*}{ NS } \\
\hline$>0.03 \mathrm{mg} / \mathrm{dl}$ & $\begin{array}{r}59(75.6 \\
\%) \\
\end{array}$ & $\begin{array}{l}11(84.6 \\
\%)\end{array}$ & $\begin{array}{r}9(100 \% \\
) \\
\end{array}$ & & \\
\hline \multicolumn{6}{|c|}{ Indirect bilirubin } \\
\hline$\leq 1 \mathrm{mg} / \mathrm{dl}$ & $\begin{array}{r}42(53.8 \\
\%)\end{array}$ & $\begin{array}{l}5(38.5 \% \\
)\end{array}$ & $\begin{array}{r}1(11.1 \% \\
)\end{array}$ & \multirow[t]{2}{*}{0.02} & \multirow[t]{2}{*}{$\mathbf{S}$} \\
\hline$>1 \mathrm{mg} / \mathrm{dl}$ & $\begin{array}{r}36(46.2 \\
\%)\end{array}$ & $\begin{array}{l}8(61.5 \% \\
)\end{array}$ & $\begin{array}{r}8(88.9 \\
\%)\end{array}$ & & \\
\hline
\end{tabular}


ISSN: 2536-9474 (Print) ISSN: 2536-9482 (Online)
Original article / FYMJ

Fayoum University Medical Journal Lotayef et al., 2020,7(1), 16-24

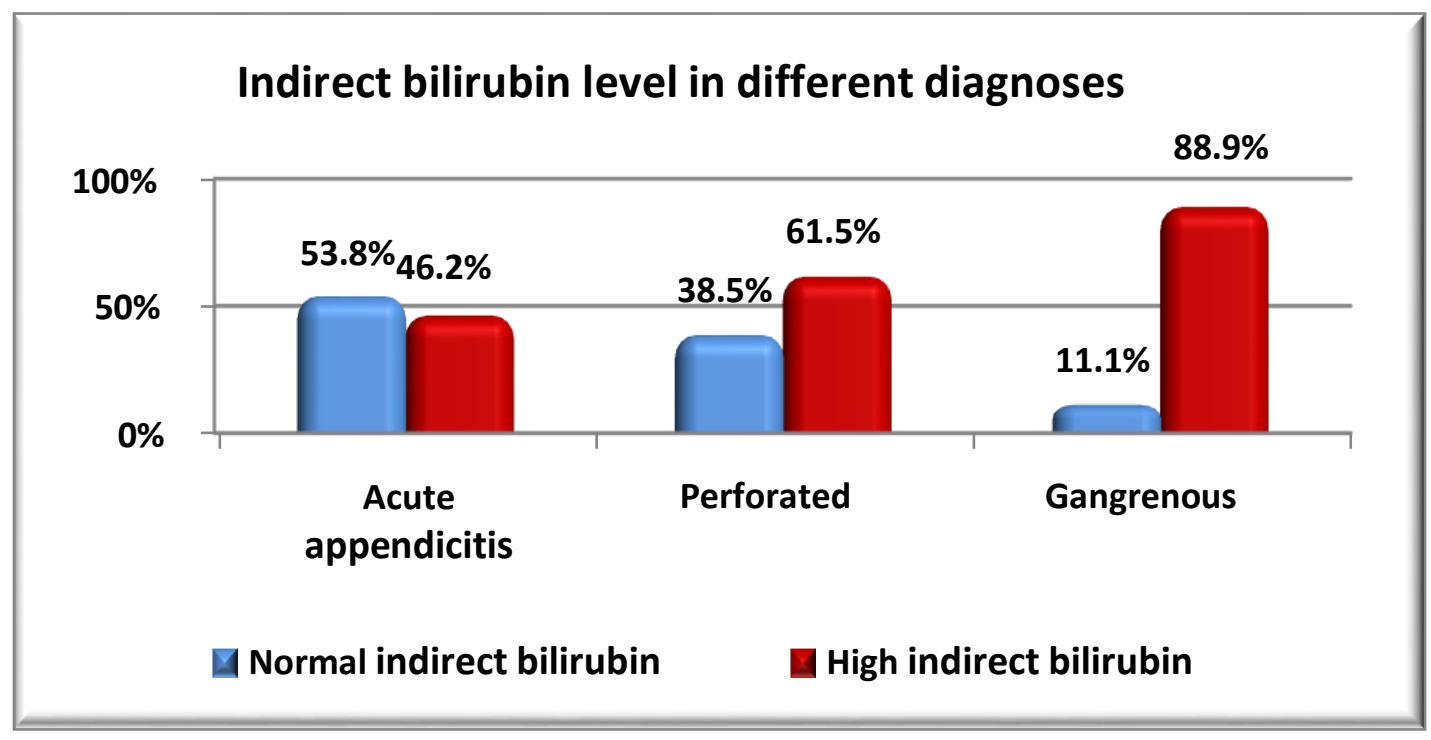

